\title{
Carbon Footprint Assessment of Sweet Cherry Production: Hotspots and Improvement Options
}

\author{
Grecia Bravo", Diego López ${ }^{1}$, Marcia Vásquez², Alfredo Iriarte ${ }^{3,4 *}$ \\ ${ }^{1}$ School of Industrial Civil Engineering, Faculty of Engineering, Universidad de Talca, \\ Casilla 747, Talca, Chile \\ ${ }^{2}$ Forestry Department of Environmental Management, Faculty of Forest Science, Universidad de Talca, \\ Casilla 747, Talca, Chile \\ ${ }^{3}$ Department of Industrial Engineering, Faculty of Engineering, Universidad de Talca, \\ Casilla 747, Talca, Chile \\ ${ }^{4}$ Chilean Food Processing Research Center (CEAP), R09I2001, Av. San Luis km 1, Talca, Chile
}

Received: 9 August 2016

Accepted: 26 September 2016

\begin{abstract}
The carbon footprint (CF) evaluates the overall amount of greenhouse gas emissions and removals associated with a product or activity across its life cycle. Today, the CF assessment has the potential to be a key measurement for increasing sustainable agricultural production. In addition, the export-oriented fruit sector has been challenged to quantify and reduce their CF. Worldwide there are scant peer-review studies that examine the $\mathrm{CF}$ of stone fruits (Prunus genus). The scarcity is most evident in sweet cherries, which is the third most exported stone fruit in the world in terms of value (after almonds and peaches). Chile is the largest southern hemisphere producer and exporter of sweet cherry fruit. Within this context, the present study is one of the first assessments of the CF of conventional sweet cherry production. This work considers Chilean agricultural practices and identifies key influencing factors (hotspots). It takes into account the following agricultural inputs: mineral fertilizers, pesticides, diesel consumption for agricultural operations, machinery, and electricity for irrigation. The results indicate that the average CF of the Chilean sweet cherry production is $0.41 \mathrm{~kg} \mathrm{CO}$-eq $/ \mathrm{kg}$ of harvested fruit, with a $95 \%$ confidence interval between 0.36 and $0.47 \mathrm{~kg} \mathrm{CO}_{2}$-eq $/ \mathrm{kg}$. This value is higher than those for other stone fruits reported by the literature. Diesel and fertilizers are the most important contributors to the CF of sweet cherry cultivation. Improvement scenarios are evaluated for the hotspots in order to reduce greenhouse gas emissions from the production of this fruit. This study provides quantitative environmental criteria associated with global warming concerns to the stakeholders in the fruit sector and to the agricultural policymakers.
\end{abstract}

Keywords: carbon footprint, life cycle assessment (LCA), GHG emissions, agricultural sustainability assessment, perennial crops

*e-mail: airiarte@utalca.cl 


\section{Introduction}

The increasing rate of population growth has put pressure on food chain production. To improve land productivity in agriculture, the use of resources such as water, agrochemicals, and energy causes a wide range of implications to environmental sustainability. The life cycle assessment (LCA) is a methodology to identify quantitatively the environmental impacts of energy and materials, as well as waste and emissions in products, processes, or activities during its lifetime [1]. LCA applied in agricultural systems are continually increasing due to environmental impacts related to agricultural activities such as water consumption [2]; land conversion with its associated loss of biodiversity [3]; the use of pesticides, herbicides, and fungicides [4-6]; and energy use [7]. In a methodological framework, the carbon footprint (CF) is a subset of the indicators covered by the LCA methodology [8]. According to the PAS 2050-1 standard [9], the CF evaluates the overall amount of greenhouse gas (GHG) emissions and removals associated with a product or activity across its life cycle. The $\mathrm{CF}$ has been rising in importance in the international trade world. In agricultural production, such as other sectors, the CF assessment can identify emission reduction options in order to improve environmental sustainability associated with global warming concerns.

The contribution made by fruits to GHG emissions from household food consumption of some developed countries can be similar to that of seafood, grain products, or other foods $[10,11]$. Some studies have assessed the $\mathrm{CF}$ or a range of environmental impacts produced by fresh fruit produced in temperate regions by applying the LCA approach. For example, Milà and Canals et al. [12] analyzed apple production in New Zealand via LCA, and Liu et al. [13] examined pear production in China. Page et al. [14] performed an analysis of organic kiwi and apple production in New Zealand based on a CF study. Sanjuan et al. [15] conducted an LCA study of integrated production of oranges in Valencia, Spain, and Cordes et al. [16] analyzed the CF of blueberry fruit in Chile under organic production. Worldwide, there are scant peerreview studies that examine the $\mathrm{CF}$ of stone fruits (Prunus genus). When focusing on environmental burdens of sweet cherry (Prunus avium L.) production, the scarcity is most evident. It is worth highlighting the work of Litskas et al. [17], who analyzed energy use and GHG emissions of cherry orchards in Greece.

After almonds and peaches, the sweet cherry is the third most exported stone fruit in the world in terms of value [18]. Chile is the largest southern hemisphere producer and exporter of sweet cherry fruit and it is the sixth largest cherry producer in the world. Chilean sweet cherry production reached a volume of 110,900 tons in 2015 [19]. The main destination markets for the Chilean cherry are Asia (including Hong Kong and China), with $69 \%$ of exported volume and the United States with $16 \%$ participation [19]. Today, the export-oriented agricultural sector is dependent on the environmental framework in destination countries [20]. The fruit production sector in Chile, such as the worldwide fruit sector, faces CF reduction challenges due to changing international consumer demands and entry market policies in the world trading system [21].

The lack of information about GHG emissions of sweet cherry cultivation on a worldwide scale and the need to reduce its emissions justifies the evaluation of the $\mathrm{CF}$ of this fruit. In this context, this study takes the first steps to assess the CF of sweet cherry production in Chile, in order to identify its key influence factors and to provide environmental criteria to the agricultural stakeholder for improving carbon efficiency of this fruit. This study may also help make decisions in other countries where there is similar agricultural production for stone fruits.

\section{Methodology}

The methodology used in this study follows the ISO/TS 14067 [22] framework and specific recommendations for the CF of horticultural products of PAS 2050-1 standard [9] in agreement with ISO/TS 14067. To calculate CF we used the CCaL V3.0 software developed by the University of Manchester [23]. We also used the ecoinvent 2.2 database [24].

Taking into account the above standards, this section is divided into the following subsections: 1) study objectives and functional unit, 2) system boundary, 3) study area, data source, and exclusions, and (4) considerations and assumptions.

\section{Study Objectives and Functional Unit}

The main objectives of this study were to evaluate the CF of conventional sweet cherry production under Chilean representative practices (reference situation), to identify the key influence factors (hotspots) of the CF at the farm stage and to evaluate GHG emissions reduction scenarios, in order to provide the stakeholders in the fruit sector with environmental criteria associated with global warming concerns.

The functional unit (FU) is a quantified performance of a product system for use as a reference unit [25]. In order to represent the main function of the study objectives, the FU used in this work is $1 \mathrm{~kg}$ of harvested sweet cherry under conventional production.

\section{System Boundary}

The system boundary is the basis used to determine which unit processes are included within the CF study [22]. At the same time, to be consistent with the objectives of the study, the system boundary is set from cradle-tofarm gate. The boundary is set until the harvest process. The system under assessment (see Fig. 1) involves the following agricultural inputs: 1) fertilizers (including growth regulators), 2) pesticides, 3) diesel for agricultural operations, 4) machinery (tractors, tools), and 5) electricity 


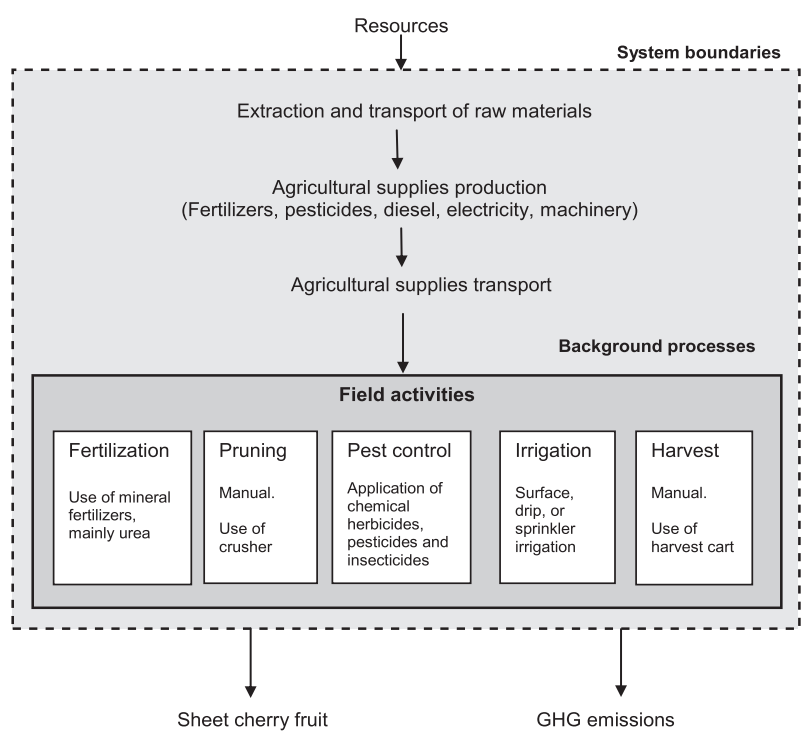

Fig. 1. System boundaries of the sweet cherry production system.

for irrigation. The life cycle of each agricultural input is included within the system boundary, and it considers the raw materials extraction (e.g., minerals, fuel), production (e.g., of fertilizers, machinery), intermediate transport, and use.

\section{Study Area, Data Source, and Exclusions}

The study area corresponds to the Maule region of Chile; located in the central area of the country (from the $35^{\text {th }}$ to $36^{\text {th }}$ parallel south), where the highest percentage of national sweet cherry cultivation is concentrated. This region represents an average of $47 \%$ of the Chilean land planted with this fruit [26].

The data from the agricultural inputs and fruit yield of sweet cherry production used in the inventory (see Table 1) correspond to agricultural practices that are representative of the Maule region conditions, and are based on technicaleconomic studies published by the National Society of Agriculture [27] and the Chilean governmental Office for Agriculture Studies and Policies [28]. These studies are based on information from agricultural companies, visits to growers, and public organizations. The previous data are complemented by field information obtained in 2015 by our research group in face-to-face interviews either with the owners or the administrators of five sweet cherry orchards.

Pruning residue treatments and residuals like packaging of agrochemicals were excluded from analyses due to lack of data. The sources of data used in this study only indicate the agricultural inputs associated to the full production stage of the sweet cherry trees. Consequently, the low and non-productive stages (e.g., nursery, planting, and growing) are not included because of lack of data, despite the recommendation of its inclusion mentioned by Bessou et al. [29].

Background processes, such as imported agrochemical production, national diesel production, transport by truck,
Table 1. Inventory of main agricultural inputs and seed yield of Chilean sweet cherry production under study (reference situation).

\begin{tabular}{|c|c|c|}
\hline Input ${ }^{\text {a }}$ & Value & Unit \\
\hline \multicolumn{3}{|c|}{ Fertilizers and growth regulators } \\
\hline Urea & 220 & $\mathrm{~kg} / \mathrm{ha}$ \\
\hline Triple superphosphate & 90 & $\mathrm{~kg} / \mathrm{ha}$ \\
\hline Potassium sulfate & 110 & $\mathrm{~kg} / \mathrm{ha}$ \\
\hline Others fertilizers & 16 & $\mathrm{~kg} / \mathrm{ha}$ \\
\hline Growth regulators & 26 & $\mathrm{~kg} / \mathrm{ha}$ \\
\hline \multicolumn{3}{|c|}{ Pesticides } \\
\hline Copper hydroxychloride & 6.1 & $\mathrm{~kg} / \mathrm{ha}$ \\
\hline Chlorothalonil & 1.4 & $\mathrm{~kg} / \mathrm{ha}$ \\
\hline Iprodione & 2.0 & $\mathrm{~kg} / \mathrm{ha}$ \\
\hline Streptomycine & 0.8 & $\mathrm{~kg} / \mathrm{ha}$ \\
\hline Haloxifop-P-metil & 0.1 & $\mathrm{~kg} / \mathrm{ha}$ \\
\hline $\begin{array}{l}\text { Paraquat dichloride and diquat } \\
\text { dibromide }\end{array}$ & 0.6 & $\mathrm{~kg} / \mathrm{ha}$ \\
\hline Quizalofop-P-tefuryl & 0.4 & $\mathrm{~kg} / \mathrm{ha}$ \\
\hline Chlorpyrifos & 1.0 & $\mathrm{~kg} / \mathrm{ha}$ \\
\hline Lambda- cyhalothrin & 0.1 & $\mathrm{~kg} / \mathrm{ha}$ \\
\hline Paraffinic mineral oil & 35.1 & $\mathrm{~kg} / \mathrm{ha}$ \\
\hline Others pesticides & 0.1 & $\mathrm{~kg} / \mathrm{ha}$ \\
\hline \multicolumn{3}{|c|}{ Irrigation requirement } \\
\hline Electricity use & 2500 & $\mathrm{kWh} / \mathrm{ha}$ \\
\hline \multicolumn{3}{|c|}{ Diesel consumption } \\
\hline Crushing & 28 & $\mathrm{~kg} / \mathrm{ha}$ \\
\hline Spraying, fertilizers & 279 & $\mathrm{~kg} / \mathrm{ha}$ \\
\hline Spraying, pesticides & 56 & $\mathrm{~kg} / \mathrm{ha}$ \\
\hline Harvest & 84 & $\mathrm{~kg} / \mathrm{ha}$ \\
\hline \multicolumn{3}{|c|}{ Tools and tractor } \\
\hline Crusher & 2 & $\mathrm{~kg} / \mathrm{ha}$ \\
\hline Sprayer & 23 & $\mathrm{~kg} / \mathrm{ha}$ \\
\hline Harvest cart & 6 & $\mathrm{~kg} / \mathrm{ha}$ \\
\hline Tractor & 117 & $\mathrm{~kg} / \mathrm{ha}$ \\
\hline Seed yield & 11000 & $\mathrm{~kg} / \mathrm{ha}$ \\
\hline
\end{tabular}

${ }^{a}$ Average values

etc., are obtained from the ecoinvent 2.2 database [24]. This database has an adequate application for industrial activities in those South American countries with higher levels of technology, such as Chile [30]. Additionally, the Chilean electricity mix is incorporated to reflect local conditions. The majority of the agrochemicals used 
in sweet cherry production are imported. To the GHG emissions of the production of these products, those of the transport are added. Transport includes transportation from the country of origin in a container vessel to the port of San Antonio (Chile), from there in a large truck to the regional supplier, and from there in a pick-up vehicle or a small truck to the farm.

\section{Considerations and Assumptions \\ Representativeness and Geographical Coverage}

Considering that data are based on sector statistics from a large area, it may be assumed to be representative of the average cultivation system in the region under study. Furthermore, geographic differences are smoothed out through the average data used.

\section{Uncertainty Assessment}

The sources of data used in the present study give a set of values without the range of variation. In this case, we do not know the uncertainty of a specific input. Therefore, we use data quality indicator scores to estimate the level of uncertainty [31]. According to the GHG protocol standard for product life cycle [32], our approach includes a pedigree matrix (based on data quality scores) for quantifying single parameter uncertainty, and the Taylor series expansion to propagate individual parameter uncertainties and to determine overall system uncertainty. The approach assumes that the uncertainty distribution for each parameter is log-normally distributed [31].

\section{Nitrous Oxide Emissions}

Nitrous oxide emissions $\left(\mathrm{N}_{2} \mathrm{O}\right)$ from the application of nitrogen fertilizers have been estimated according to the Tier 1 approach stated by the IPCC [33] and using a 100-year GWP for $\mathrm{N}_{2} \mathrm{O}$ of $298 \mathrm{~kg} \mathrm{CO}_{2}$-eq $/ \mathrm{kg} \mathrm{N}_{2} \mathrm{O}$ [9].

\section{Allocation}

Allocation involves the partitioning of the inputs and outputs between co-products in a CF study of a multifunctional system. In view of the fact that the inventory in this study is based on quantities of fertilizers and other agrochemicals used exclusively for the production of sweet cherry, all agricultural inputs and outputs are completely assigned to this crop. Furthermore, since no co-products are produced from the orchards, the co-products allocation procedure is not necessary.

\section{Land Use Change}

Land use change (LUC) is the change in the purpose for which land is used by humans (e.g., the conversion from forestland to cropland). In accordance with the PAS 2050-1 guide [9], GHG emissions from LUC are not considered in this study because most Chilean sweet cherry plantations are cultivated on agricultural land that has been used for perennial crops for longer than 20 years.

\section{Results and Discussion}

The first subsection presents the $\mathrm{CF}$ results and the influence of agricultural factors on GHG emissions for sweet cherry production. The second subsection then analyzes the life cycle stages of key influence factors of the sweet cherry CF. The third subsection evaluates the GHG emission reduction scenarios related to the factors with the greatest contribution. Finally, the fourth subsection compares the GHG emission results from this study with CF studies of stone fruits available in the literature.

\section{Carbon Footprint of Sweet Cherry Production and Contribution of Agricultural Factors to GHG Emissions}

Table 2 shows the CF of sweet cherry cultivation under Chilean representative practices and the contribution of inputs to the GHG emissions. The $\mathrm{CF}$ of sweet cherry production is $0.41 \mathrm{~kg} \mathrm{CO}_{2}-\mathrm{eq} / \mathrm{kg}$ of harvested fruit on average, with a $95 \%$ confidence interval between 0.36 and $0.47 \mathrm{~kg} \mathrm{CO}$-eq $/ \mathrm{kg}$. Under average European conditions, a report conducted by Audsley et al. [34] indicated a CF for sweet cherry of $0.43 \mathrm{~kg} \mathrm{CO}$-eq $/ \mathrm{kg}$ from the agricultural production up to a UK regional distribution center. Our results do not exceed the range of 0.2 to $0.8 \mathrm{~kg} \mathrm{CO}_{2}-\mathrm{eq} / \mathrm{kg}$ according to previous case studies of horticultural products (category 6) as indicated in Table D.1 of the PAS 2050-1 [9]. However, our results are significantly lower than those reported by Litskas et al. [17]. Analyzing their results on conventional sweet cherry orchards located in northern Greece, we conclude that GHG emissions of Greek sweet cherry production were on average $1.3 \mathrm{~kg} \mathrm{CO}_{2}$-eq $/ \mathrm{kg}$ fruit. The difference between Chilean and Greek results could be explained by both the different rates of agrochemical application and the diesel used on the farms.

Table 2 also shows that the agricultural inputs of greatest contribution to the GHG emissions (hotspots) of sweet cherry production are diesel use followed by mineral fertilizers by an average of $41 \%$ and $32 \%$, respectively. These hotspots are analyzed in further detail in the next subsection. The relatively high GHG emissions associated with diesel result mainly from fuel consumption in foliar applications of agrochemicals. In relation to fertilizers, urea makes a considerable influence to the $\mathrm{CF}$ of these agrochemicals. Our results are in agreement with those of Bessou et al. [29] and Iriarte et al. [35]; from these studies, it is possible to indicate that the fertilizers contribute significantly to GHG emissions of fruit crops. On the other hand, machinery and pesticides present the lowest impact. These inputs contribute $7 \%$ on average to the total CF. 
Table 2. Contribution of agricultural inputs to the CF of Chilean sweet cherry production.

\begin{tabular}{|c|c|c|c|}
\hline Agricultural input & $\begin{array}{c}\text { Average } \\
\left(\mathrm{kg} \mathrm{CO}_{2} \text {-eq/FU }{ }^{\mathrm{a}}\right)\end{array}$ & $\begin{array}{c}\text { Lower value } \\
\left(\mathrm{kg} \mathrm{CO}_{2} \text {-eq/FU) }\right.\end{array}$ & $\begin{array}{c}\text { Upper value }^{\mathrm{b}} \\
(\mathrm{kg} \mathrm{CO} \text {-eq/FU) }\end{array}$ \\
\hline Fertilizers (including growth regulators) & 0.13 & 0.116 & 0.162 \\
\hline Pesticides & 0.01 & 0.009 & 0.012 \\
\hline Diesel & 0.17 & 0.132 & 0.218 \\
\hline Machinery (tractors, tools) & 0.02 & 0.016 & 0.025 \\
\hline Electricity for irrigation & 0.08 & 0.067 & 0.470 \\
\hline Total carbon footprint & 0.41 & 0.360 & 0.095 \\
\hline
\end{tabular}

${ }^{\mathrm{a}}$ Functional unit $=1 \mathrm{~kg}$ of harvest sweet cherry.

${ }^{b}$ Lower and upper limits of the $95 \%$ confidence interval on the uncertainty distribution.

\section{Analysis of the GHG Emissions of the Hotspots}

As mentioned in the previous subsection, diesel and mineral fertilizers are key agricultural inputs, due to their major influence on the GHG emissions of sweet cherry production in Chile. Fig. 2 shows the contribution of the main life cycle stages (production, transport, and use)

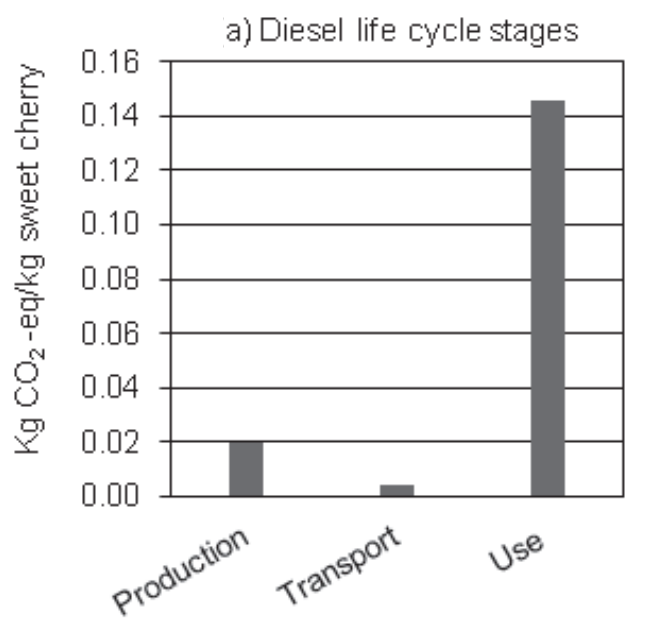

b) Fertilizer life cycle stages

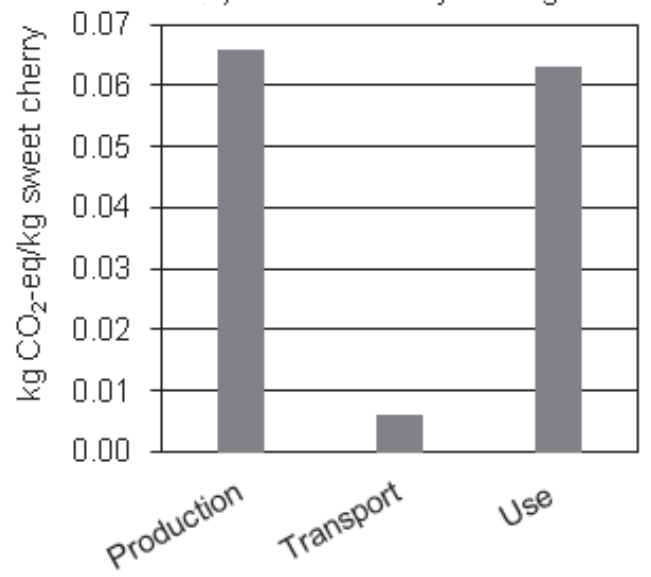

Fig. 2. GHG emissions of the life cycle stages of a) diesel and b) fertilizers used in sweet cherry cultivation. to the CF of diesel and fertilizers employed on sweet cherries. When examining the diesel life cycle stages, diesel use associated with fuel combustion on farms is the major contributor to GHG emissions in this life cycle $(86 \%)$. Within the fertilizer's life cycle, the main stages are fertilizer use (associated with field emissions, mainly $\mathrm{N}_{2} \mathrm{O}$ emissions) and fertilizer production (including extraction of raw materials). As a whole, these stages contribute $98 \%$ of the GHG emissions in this life cycle. This is in agreement with previous studies, which have shown the significant contribution of field emissions to GHG emissions in cropping systems [36-37]. In contrast, the transport stage of diesel or fertilizers from production centers to farms has a minor contribution in both life cycles, with values between $1 \%$ and $2 \%$.

\section{GHG Emission Reduction Scenarios}

Three reduction scenarios based on the agricultural inputs of greatest contribution to the GHG emissions of sweet cherry production (fertilizers and diesel) are proposed according to the Pareto Principle [38]. Furthermore, the orchard practices informed by farmers in the Maule region are considered when defining these scenarios.

Scenario 1 considers a change of fertilizer. The type of mineral fertilizer applied differs among orchards. This scenario proposes the replacement of urea (a major contributor to the GHG emissions of fertilizers) for calcium nitrate.

Scenario 2 considers a reduction of the amount of fertilizers applied. According to data gathered in the field, the amount of total fertilizers applied differs among farms. A reasonable scenario considers a $25 \%$ reduction in the amount of total fertilizers with regard to the reference situation.

Scenario 3 considers a reduction of diesel use for agricultural operations. Some sweet cherry farmers apply pesticides by manual backpack sprayers instead of applications by tractors, reducing its diesel use in comparison to the others. This scenario proposes a $30 \%$ reduction in the amount of diesel used for agricultural labor. 


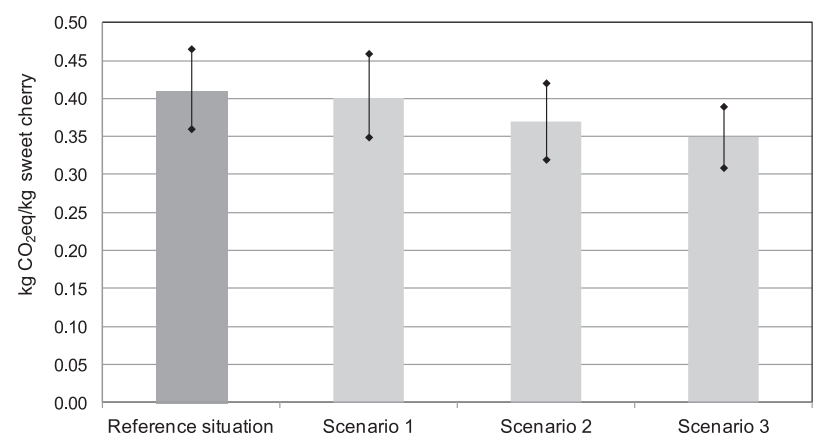

Fig. 3. CF for the GHG reduction scenarios of sweet cherry production in comparison to the reference situation. The bars show the mean values and the lines indicate the lower and upper limits of the $95 \%$ confidence interval.

As shown in Fig. 3, we observed that when evaluating the measures suggested in the scenarios, the diesel diminution for agricultural operations (scenario 3) achieves the greatest reduction of the GHG emissions of sweet cherry production (15\%). The reduction of fertilizer application (scenario 2) could decrease GHG emissions by $8 \%$ compared to the reference situation. On the other hand, the results indicate that the replacement of urea for calcium nitrate (scenario 1) only reduces the CF by $2 \%$. The diesel diminution associated with a major use of manual backpack sprayers would have the highest positive impact on reducing CF of sweet cherry cultivation, but orchard size and high labor costs have to be considered for each particular situation. In the same way, diesel use can be reduced by replacing existing tractors by more efficient units.

\section{Comparison with other CF Studies of Stone Fruits}

There are scant peer-review studies that have examined the CF of stone fruits (Prunus genus). According to a literature review of these studies, the calculated $\mathrm{CF}$ of $0.41 \mathrm{~kg} \mathrm{CO}-\mathrm{eq} / \mathrm{kg}$ for sweet cherry production could be mitigated by a more organic orchard system, such as less consumption of synthetic fertilizer or substitution with manure, and less energy consumption due to accurate diesel use. The GHG emissions of almond production in California, USA were $0.9 \mathrm{~kg} \mathrm{CO}$-eq/ $/ \mathrm{kg}$ almond applying allocation methods by co-product of orchard biomass and shells used in electricity generation, where the main contributor of GHG emissions were nitrogen fertilizer and energy for irrigation [39]. Some research conducted with peaches in different countries showed an estimated $\mathrm{CF}$ between 0.1 to $0.16 \mathrm{~kg} \mathrm{CO}_{2}$-eq $/ \mathrm{kg}$ peaches using organic, integrated, and conventional farming systems in Greece [40]; a CF of $0.23 \mathrm{~kg} \mathrm{CO}$-eq/kg in Italy [41]; and a $\mathrm{CF}$ of $0.37 \mathrm{~kg} \mathrm{CO}$-eq/kg in China [42], where the main contributor was mineral nitrogen fertilizer at more than $50 \%$.

\section{Conclusions}

The CF assessment allows planning and promoting of widespread low-carbon procedures across fruit companies, as well as policymakers and other stakeholders on the subject. There are scant studies that have examined the CF of stone fruits. In this context, this study is one of the first assessments of the $\mathrm{CF}$ of sweet cherry production worldwide.

The CF of conventional sweet cherry production under representative practices in the main cultivation region of Chile is $0.41 \mathrm{~kg} \mathrm{CO}$-eq $/ \mathrm{kg}$ of harvested fruit, with a $95 \%$ confidence interval between 0.36 and $0.47 \mathrm{~kg}$ $\mathrm{CO}_{2}$-eq $/ \mathrm{kg}$. The main contributors to the $\mathrm{GHG}$ emissions of sweet cherry production are diesel for field operations and mineral fertilizers. On the other hand, machinery and pesticides present the lowest impact.

In order to minimize the GHG emissions associated with diesel consumption, a major use of manual backpack sprayers, instead of applications by tractors, should be evaluated. However, this might be only partially applicable due to high labor costs and orchard size. The results of the GHG emissions reduction scenarios show that a $30 \%$ reduction in diesel owing to a major use of manual sprayers could decrease the CF of sweet cherry production by $15 \%$ compared to the reference situation. In addition, diesel use can be reduced by replacing existing tractors with new machines that are more efficient, as the results at some orchards have shown.

Reducing the fertilizer application would have a positive impact on reducing CF of sweet cherry production, but crop requirements have to be considered to avoid yield reduction. Furthermore, other sources of fertilizers could be desirable if the GHG emissions are to be improved. The use of livestock manure as an organic fertilizer for Chilean sweet cherry orchards is a possible option. According to our results, the $\mathrm{N}_{2} \mathrm{O}$ emissions from applying fertilizers are a high contributor to GHG emissions of sweet cherry cultivation. These emissions are influenced by a large number of local parameters - one of the main ones being the amount of nitrogen available in the soil. Thus, more efficient fertilization strategies will lead to a decrease of $\mathrm{N}_{2} \mathrm{O}$ emissions.

New field data or evaluation of CF on other life cycle stages, such as packing and transportation from orchards to customers, could further improve knowledge of the CF of sweet cherries in order to reduce the GHG emissions of this fruit. Furthermore, future environmental studies of Chilean sweet cherry production could incorporate the use of more technology for cultivation. Even so, some technology could increase the CF if the goal is minimizing harvesting time by using mechanical devices. Additionally, determining impact categories, such as eutrophication, acidification, and impacts related to water use, could be added to develop a more complete LCA. We encourage further research in that direction. 


\section{Acknowledgements}

We thank CONICYT (Chile) - FONDECYT Project No. 11140765 for supporting the present work. We also thank sweet cherry growers for their help in providing data and their participation in this research.

\section{References}

1. ISO (International Organization of Standardization). ISO 14040: 2006 Environmental management - life cycle assessment - principles and framework. Geneva, Switzerland, 2006.

2. NÚÑEZ M., PFISTER S., ANTÓN A., MUÑOZ P., HELLWEG S., KOEHLER A., RIERADEVALL J. Assessing the environmental impact of water consumption by energy crops grown in Spain. J. Ind. Ecol. 17 (1), 90, 2013. http://dx.doi.org/10.1111/j.1530-9290.2011.00449.x

3. VITOUSEK P.M., MOONEY H.A., LUBCHENCO J., MELILLO J.M. Human Domination of Earth's Ecosystems. Science. 277 (5325), 494, 1997. http://dx.doi.org/10.1126/ science. 277.5325 .494

4. ALAPHILIPPE A., SIMON S., BRUN L., HAYER F., GAILLARD G. Life cycle analysis reveals higher agroecological benefits of organic and low-input apple production. Agron. Sustain. Dev. 33(3), 581, 2012, http:// dx.doi.org/10.1007/s13593-012-0124-7

5. CROSS P., EDWARDS-JONES G. Variation in pesticide hazard from arable crop production in Great Britain from 1992 to 2002: Pesticide risk indices and policy analysis. Crop Protect. 25(10), 1101, 2006. http://dx.doi.org/10.1016/j. cropro.2006.02.013

6. MAMY L., GABRIELLE B., BARRIUSO E. Comparative environmental impacts of glyphosate and conventional herbicides when used with glyphosate-tolerant and nontolerant crops. Environ. Pollut. 158 (10), 3172, 2010. http://dx.doi.org/10.1016/j.envpol.2010.06.036

7. GIRGENTI V., PEANO C., BOUNOUS M., BAUDINO C. A life cycle assessment of non-renewable energy use and greenhouse gas emissions associated with blueberry and raspberry production in northern Italy. Sci. Total. Environ. 458-460, 414, 2013. http://dx.doi.org/10.1016/j. scitotenv.2013.04.060

8. EPLCA. Carbon footprint - What it is and how to measure it. European Platform on Life Cycle Assessment (EPLCA), Joint Research Centre - Institute for Environment and Sustainability. Ispra, Italy, 2007.

9. BSI PAS 2050-1:2012. Assessment of life cycle greenhouse gas emissions from horticultural products. British Standards Institution (BSI), London, United Kingdom, 2012.

10. BINA S., DOWLATABADIB H. Consumer lifestyle approach to US energy use and the related $\mathrm{CO}_{2}$ emissions. Energ. Policy. 33,197, 2005. http://dx.doi.org/10.1016/ S0301-4215(03)00210-6

11. KRAMER K., MOLL H., NONHEBEL S., WILTING H. Greenhouse gas emissions related to Dutch food consumption. Energ. Policy. 27, 203, 1999. http://dx.doi. org/10.1016/S0301-4215(99)00014-2

12. MILÀ I CANALS L., BURNIP G., COWELL S. Evaluation of the environmental impacts of apple production using Life Cycle Assessment (LCA): Case study in New Zealand. Agric. Ecosyst. Environ. 114, 226, 2006. http://dx.doi. org/10.1016/j.agee.2005.10.023
13. LIU Y., LANGER V., HØGH-JENSEN H., EGELYNG H. Life cycle assessment of fossil energy use and greenhouse gas emissions in Chinese pear production. J. Clean. Prod. 18, 1423, 2010. http://dx.doi.org/10.1016/j. jclepro.2010.05.025

14. PAGE G., KELLY T., MINOR M., CAMERON M. Modeling carbon footprints of organic orchard production systems to address carbon trading: An approach based on life cycle assessment. HortScience. 46, 324, 2011.

15. SANJUAN N., UBEDA L., CLEMENTE G., MULET A. LCA of integrated orange production in the Comunidad Valenciana (Spain). Int. J. Agric. Resources Govern. Ecol. 4 (2), 163, 2005. http://dx.doi.org/10.1504/ IJARGE.2005.007198

16. CORDES H., IRIARTE A., VILLALOBOS P. Evaluating the carbon footprint of Chilean organic blueberry production. Int. J. Life Cycle Assess. 21, 281, 2016. http://dx.doi. org/10.1007/s11367-016-1034-8

17. LITSKAS V., MAMOLOS A., KALBURTJI K., TSATSARELIS C., KIOSE-KAMPASAKALI E. Energy flow and greenhouse gas emissions in organic and conventional sweet cherry orchards located in or close to Natura 2000 sites. Biomass Bioenerg. 35 (3), 1302, 2011. http://dx.doi.org/10.1016/j.biombioe.2010.12.023

18. FAOSTAT. Food and Agriculture Organization Corporate Statistical Database. Food and Agriculture Organization (FAO). 2016. http://faostat3.fao.org/download/Q/QC/E

19. MUÑOZ M. Sweet cherry: fruits in expansion. Office of Agricultural Policies and studies (ODEPA). Ministry of Agriculture - Chile. Santiago, Chile, 2015 [In Spanish].

20. ODEPA (OFFICE OF AGRICULTURAL POLICIES AND STUDIES). Insertion of the Chilean agriculture on the international markets. Ministry of Agriculture - Chile. Santiago, Chile, 2013 [In Spanish].

21. FDF. Guide of good practices of sustainability in the fruit industry of Chile. Foundation for Fruit Development (FDF). Santiago, Chile, 2013 [In Spanish].

22. ISO (INTERNATIONAL ORGANIZATION FOR STANDARDIZATION). ISO/TS 14067:2013. Greenhouse gases - Carbon footprint of products- Requirements and guidelines for quantification and communication. Geneva, Switzerland, 2013.

23. CCaLC. Carbon Calculations over the Life Cycle of Industrial products. Carbon footprinting tool, 2016. http:// www.ccalc.org.uk

24. SWISS CENTRE FOR LCI. The Ecoinvent database. Swiss Centre for Life Cycle Inventories, 2016. http://www. ecoinvent.org/about-us/

25. BSI (BRITISH STANDARDS INSTITUTION). PAS 2050:2011. Specification for the assessment of life cycle greenhouse gas emissions of goods and services. London, United Kingdom, 2011.

26. BRAVO J. Sweet cherry: update of a market. Office of Agricultural Policies and Studies (ODEPA). Ministry of Agriculture - Chile. Santiago, Chile. 2013 [In Spanish].

27. SNA (NATIONAL AGRICULTURAL SOCIETY). Technical data sheet of sweet cherry. Department of studies. SNA. Santiago, Chile, 2015 [In Spanish]. http://www.sna.cl/ estudios/fichas-tecnicas/

28. ODEPA (OFFICE OF AGRICULTURAL POLICIES AND STUDIES). Cost of production of sweet cherry in the Maule region. Ministry of Agriculture - Chile. Santiago, Chile, 2015 [In Spanish]. http://www.odepa.cl/costo-de-produccion-delcerezo/

29. BESSOU C., BASSET-MENS C., TRAN T., BENOIST A. LCA applied to perennial cropping systems: A review 
focused on the farm stage. Int. J. Life Cycle Assess. 18, 340, 2013. http://dx.doi.org/10.1007\%2Fs11367-012-0502-z

30. OSSÉS DE EICKER M., HISCHIER R., HURNI H., ZAH R. Using non-local databases for the environmental assessment of industrial activities: the case of Latin America. Environ. Impact Assess. Rev. 30, 145, 2010. http://dx.doi. org/10.1016/j.eiar.2009.08.003

31. FRISCHKNECHT R., JUNGBLUTH N., ALTHAUS H.J., DOKA G., HECK T., HELLWEG S., HISCHIER R., NEMECEK T., REBITZER G., SPIELMANN M., WERNET G. Overview and methodology. Ecoinvent report No. 1. Swiss Centre for Life Cycle Inventories, Dübendorf, 2007.

32. GHG PROTOCOL. Quantitative Uncertainty Guidance. Product Life Cycle Accounting and Reporting Standard. The Greenhouse Gas Protocol, 2011. http://www. ghgprotocol. org /standards/ product-standard

33. IPCC. IPCC guidelines for National Greenhouse Gas Inventories, Chapter 11: $\mathrm{N}_{2} \mathrm{O}$ emissions from managed soils, and $\mathrm{CO}_{2}$ emissions from line and urea application. Institute for Global Environmental Strategies. Hayama, Japan, 2006.

34. AUDSLEY E., BRANDER M., CHATTERTON J., MURPHY-BOKERN D., WEBSTER C., WILLIAMS A. How low can we go? An assessment of greenhouse gas emissions from the UK food system and the scope to reduce them by 2050. FCRN-WWF-UK, 2009.

35. IRIARTE A., ALMEIDA M.G., VILLALOBOS P. Carbon footprint of premium quality export bananas: Case study in Ecuador, the world's largest exporter. Sci. Total. Environ. 472, 1082, 2014. http://dx.doi.org/10.1016/j. scitotenv.2013.11.072

36. BRITO DE FIGUEIRÊDO M.C., KROEZE C., POTTING J. The carbon footprint of exported Brazilian yellow melon.
J. Clean. Prod. 47, 404, 2012. http://dx.doi.org/ 10.1016/j. jclepro.2012.09.015

37. GASOL C., GABARRELL X., ANTON A., RIGOLA M., CARRASCO J., CIRIA P. Life cycle assessment of a Brassica carinata bioenergy cropping system in southern Europe. Biomass Bioenerg. 31 (8), 543, 2007. http://dx.doi. org/10.1016/j.biombioe.2007.01.02

38. HRAMIS J. Administrative Systems and Procedures: Methodology for Application in Private and Public Institutions. Universidad Iberoamericana, México, D.F., 1994 [In Spanish].

39. KENDALL A., MARVINNEY E., BRODT S., ZHU W. Life Cycle-based Assessment of energy use and greenhouse gas emissions in almond production, Part I: Analytical framework and baseline results. J. Ind. Ecol. 19, 1008, 2015. http://dx.doi.org/10.1111/jiec.12332

40. MICHOS M., MAMOLOS A., MENEXES G., TSATSARELIS C., TSIRAKOGLOU V., KALBURTJI K. Energy inputs, outputs and greenhouse gas emissions in organic, integrated and conventional peach orchards. Ecol. Indic. 13 (1), 22, 2012. http://dx.doi.org/10.1016/j. ecolind.2011.05.002

41. INGRAO C., MATARAZZO A., TRICASE C., CLASADONTE M.T., HUISINGH D. Life cycle assessment for highlighting environmental hotspots in Sicilian peach production systems. J. Clean. Prod. 92, 109, 2015. http:// dx.doi.org/10.1016/j.jclepro.2014.12.053

42. YAN M., CHENG K., YUE Q., YAN Y., REES R., PAN G. Farm and product carbon footprint of China's fruit production - life cycle inventory of representative orchards of five major fruits. Environ. Sci. Pollut. Res. 23, 4681, 2016. http://dx.doi.org/10.1007/s11356-015-5670-5 